\title{
Arhitektonska baština franjevaca trećoredaca na Kvarnerskim otocima (1. dio)*
}

\begin{abstract}
U radu koji predstavlja prvi dio pregleda arhitektonske baštine franjevaca trećoredaca na Kvarnerskim otocima analiziraju se položaj, arhitektura i dekorativna arhitektonska plastika dviju trećoredskih crkava, crkve sv. Franje pokraj sjevernih gradskih vrata Krka i crkve sv. Frane na Komrčaru, izvan rapskih gradskih zidina. Autor se osvrnuo i na važne elemente arhitekture samostanskih cjelina. Oba primjera, svaki na svoj način, izuzetni su u cjelini krčkih trećoredskih crkava Kvarnerskih otoka. U prvome, koji su trećoreci preuzeli tek koncem 18. stoljeća, analizira se u određenoj mjeri sačuvani predfranjevački arhitektonski sloj, koji se povezuje s crkvom benediktinskog priorata sv. Ivana, samostanom koji se prije franjevačkog nalazio na poziciji uz sjeverne zidine grada Krka. Gotički sloj ocjenjuje se reduciranim odjekom pulske franjevačke crkve. Pritom se upozorava na njegovo značenje u implementaciji novog tipa svetišta na otoku Krku. Naglasak je na sloju produljenja crkve u kasnom 15. stoljeću i okolnostima koje su dovele do toga zahvata, dok se u prirodnom se kontinuitetu dovršavanja toga projekta tumače i radovi koji su uslijedili u 16. stoljeću, a koji se nisu razmatrali u dosadašnjim objavama. Komrčarski primjer valorizira se $u$ kontekstu okolnosti koje su dovele do izgradnje crkve i samostana na tom lokalitetu izvan rapskih gradskih zidina. Posebna se pozornost pridaje dosad slabo valoriziranim elementima dekoracije crkvene unutrašnjosti. Crkva se valorizira u ključu prihvaćanja all'antica elemenata arhitektonske dekoracije na području otoka sjevernoga Jadrana.
\end{abstract}

\section{Uvod}

Uz Poviestne crte Stjepana Ivančića, do danas temeljno historiografsko djelo o povijesti trećoredaca na istočnoj obali Jadrana, ${ }^{1}$ niz novijih povijesnih priloga koji će se citirati u ovoj raspravi, kao i dvije povijesno-umjetničke sinteze o arhitekturi franjevačkih crkava na hrvatskoj obali Jadrana ${ }^{2}$, možda će se učiniti nepotrebnim

\footnotetext{
Terenski dio rada poduprli su Hrvatska zaklada za znanost projektom Croatian Medieval Heritage in European Context: Mobility of Artists and Transfer of Forms, Functions and Ideas (6095, CROMART) i Sveučilište u Rijeci projektom Umjetnička baština kasnog srednjeg $i$ ranog novog vijeka u Rijeci, na Kvarneru i u Istri.

1 IVANČIĆ 1910: 217-231. Navode se stranice koje se odnose na trećoredske samostane Kvarnerskih otoka.

2 DEMONJA 2013; I. FISKOVIĆ 2016.
} 
posvetiti se jednoj skupini povijesnih jadranskih franjevačkih samostana, $i$ to onoj na prvi pogled daleko najskromnijoj, proizišloj iz djelatnosti trećoredskog ogranka franjevačkog reda. Koncentriranjem na specifičnosti trećoredskih arhitektonskih sklopova na Kvarnerskim otocima, u ovom radu, kao i u onom koji će za njim uslijediti, objelodanit će se dosad slabo poznata i nepoznata zapažanja o ovoj arhitektonskoj baštini u kontekstu ukupne franjevačke ostavštine duž istočne obale Jadrana. Analiza je kronološki usredotočena na razdoblje kasnog srednjeg i početak ranog novog vijeka - doba osnutka i prve izgradnje trećoredskih samostanskih sklopova na Kvarneru - uz zapažanja o ranije postojećim arhitektonskim slojevima na pojedinim lokacijama, okolnostima koje su pratile pojedine pothvate gradnje i pregradnje, kao i o akterima koji su u njima sudjelovali. Rad se pojedinim naglascima samo dotiče kasnijeg razdoblja ranog novog vijeka, uz zapažanje da je riječ o zasebnom arhitektonskom sloju izgradnje samostanskih zgrada i pregradnje crkava, koje je povijesno-umjetnički uobičajeno definirati barokizacijom. Te se aktivnosti već preciznije mogu pratiti u pisanim izvorima, uključivši imena šire poznatih majstora graditelja i kipara, te će u budućnosti sasvim sigurno biti u fokusu povijesno-umjetničkih istraživanja. Cjelokupnom analizom obuhvatit će se uobičajeni ladanjski,trećoredski kvarnerski lokaliteti, na Glavotoku i u Portu, ${ }^{3}$ na otoku Krku te u uvali Bijar pokraj Osora i Martinšćici na Cresu, no oni će se prezentirati u nastavku rada. Ovaj je prvi dio posvećen donekle izuzetnim primjerima, krčkom gradskom samostanu, koji su trećoreci preuzeli koncem 18. stoljeća, i samostanu sv. Frane na Komrčaru, nadomak rapskih gradskih zidina. Neće se analizirati gostinjac u Velom Lošinju koji su trećoreci preuzeli 1895. godine jer kronološki posve izlazi izvan okvira teme. ${ }^{4} \mathrm{U}$ pogledu grafičkog materijala, ovaj rad zbog nedostatka prostora nije ilustriran nedavno u više navrata objavljenim, pa stoga i šire dostupnim tlocrtima i presjecima crkava koji se u njemu citiraju, već je naglasak na dosad neobjavljivanoj dokumentaciji, kao dopuni pojedinim primjerima već bogate dosadašnje rasprave. ${ }^{5}$

Krčke trećoredske ladanjske samostane na Glavotoku i u Portu jednom smo već opsežnije analizirali. Usp. BRADANOVIĆ 2011: 231-258.

4 IVANČIĆ 1910: 231-232.

5 Što se tiče objavljenog materijala, ponajprije mislimo na opsežnu, mjerilom usklađenu arhitektonsku dokumentaciju franjevačkih crkava primorske Hrvatske objavljenu u monografijama D. Demonje i I. Fiskovića, kao rad arhitekata Ivana Tenšeka, Ivane Valjato Vrus i Davora Zuljana. Ona je zbog karaktera izdanja i načina publiciranja, često u vidu komparativnih tablica, donekle nužno shematska, tako da ne predstavlja posve realan prikaz (npr. određenih zakrivljenosti pružanja ziđa), iznimno važan u analizi ranijih arhitektonskih slojeva, često zapretenih u naknadnim, franjevačkim pregradnjama. Nepravilnosti su vidljive u nekim drugim raspoloživim tlocrtima, osobito onima koji uz crkvena zdanja obuhvaćaju i pripadajuće samostanske komplekse, no takve su u pravilu naručivali franjevci te su nastali iz pera građevinara, pa im nedostaje dokumentiranje svodova i drugih elemenata važnih za povijesno-umjetničku analizu. 


\section{Samostan i crkva sv. Franje u gradu Krku}

Iako su samostan sv. Franje u gradu Krku trećoreci preuzeli tek 1783. godi$n^{6}$, zbog iznimne slojevitosti i starosti toga zdanja upravo njime započinjemo povijesno-umjetnički prikaz trećoredskih samostana na Kvarnerskim otocima. $\mathrm{Na}$ eliptičnom, u temeljima pretpovijesnom arealu pružanja krčkih gradskih zidina samostan zauzima njihov sami vršak pokraj sjevernih gradskih vrata Porte Sù (perior). Iako smješten unutar zidina, ovaj je prostor u srednjem i ranom novom vijeku bio suburbanog karaktera. Podno njega, unutar krčkih gradskih zidina, od zapada prema istoku pružali su se i danas postojeći ženski benediktinski samostan Gospe od Anđela, ukinuti samostan klarisa s crkvom Marijina Navještenja i benediktinski samostan sv. Mihovila, od kojeg je preostala crkva koja danas nosi titular Gospe od Zdravlja. Odreda su se unutar zatvorenih samostanskih cjelina, kako je i uobičajeno uz samostanske zgrade i dvorišta, pružali prostrani vrtovi. Dok samostan sv. Franje zauzima područje uz sjeverne gradske zidine, dijelom se koristeći njima kao svojom sjevernom fasadom, crkva se pruža južno od njega. Pročeljem je orijentirana prema samostanskom vrtu, začeljem prema gradskim vratima, sjevernim zidom prema klaustru, a južnim prema Trgu krčkih glagoljaša, koji je u srednjem vijeku nosio logično ime sv. Mihovila, prema crkvi u koju se s njega moglo neposredno kročiti. ${ }^{7}$

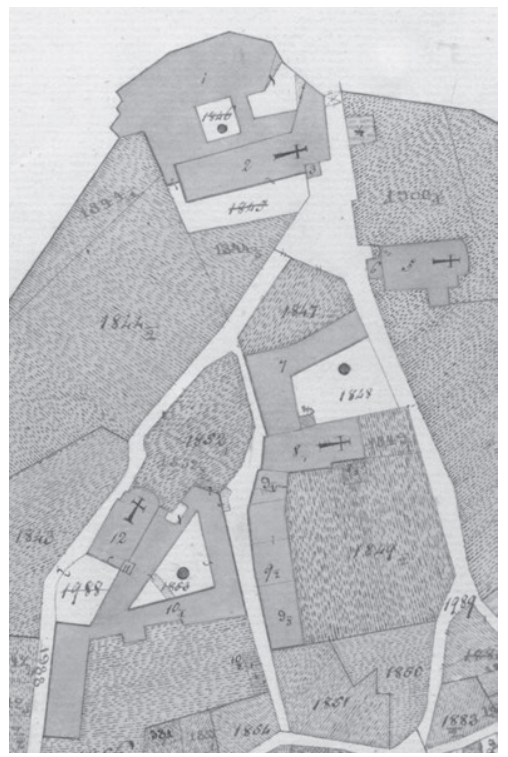

Slika. 1: Sjeverni dio grada Krka na katastarskoj mapi iz 1821. godine

\footnotetext{
IVANČIĆ 1910: 280.

7 ŽIC-ROKOV 1971: 214.
} 
Temeljnu povijesno-umjetničku deskripciju samostanske crkve sv. Franje, smještene pokraj sjevernih gradskih zidina Krka, prije nekoliko godina objavio je Damir Demonja, zaključno je povezavši s tlocrtnim oblikovanjem crkve sv. Franje u Poreču, a njezin postanak okvirno i široko datirajući u rasponu od konca 13. do polovine 14. stoljeća, pritom se pozivajući i na prethodnu historiografsku raspravu. ${ }^{8}$ Demonja je zapazio okolnost produljenja crkvene lađe, uočavajući i opisujući razlike u zidnom slogu, zbog toga vidljive reške $u$ zidu, kao i asimetrični raspored gotičkih prozorskih otvora koji nedostaju u prednjem dijelu južnog zida pročelja. Zatim je Igor Fisković tekstom i objavom shematskog tlocrta dodatno istaknuo okolnost produljenja crkvene lađe, ${ }^{9}$ povezujući ga sa sličnim rješenjima kod crkava sv. Dominika u Trogiru i Zadru, kao i sv. Franje u Poreču. Isti je autor nadalje usporedio figuralne konzole svetišta našeg primjera s onima u Poreču i Zadru, ističući da su u Krku one „najtvrđe“ izvedene. Krčki primjer nabraja i u kontekstu podteme o pregradama korova franjevačkih crkava. Istaknuo je i sličnost rješenja smještaja zvonika uz bok svetišta na primjeru crkve sv. Franje u Krku i one sv. Dominika u Trogiru. ${ }^{10}$

Ovdje valja istaknuti kako je danas već posve jasno da je jednobrodna crkva sv. Franje u Krku, zaključena pravokutnim svetištem svođenim križno-rebrastim svodom, nastala na podlozi crkve benediktinskog priorata sv. Ivana. ${ }^{11}$ Iako arheološki zahvat nije izvršen, realno je, komparativno sagledavajući, očekivati da je prva crkva imala polukružno istaknutu apsidu. Značajne ostatke romaničke crkve uočili smo i prezentirali konzervatorskim zaštitnim zahvatom izvršenim prije petnaestak godina. Prvenstveno se to odnosi na dio sjevernog zida crkve, prilikom toga zahvata očišćenog od žbuke i danas vidljivog u klaustru samostana. ${ }^{12}$ Taj opus čine izduljeni priklesani kvadri karakteristični za romaničku arhitekturu. Na sjevernom zidu u građi ziđa najbolje je uočljiva i velika razlika između opisane romaničke sekcije vidljive u hodniku klaustra i gotičkog sloga, koji se nad romaničkim pruža u elevaciji iznad krovišta, iako je sam gotički slog ovdje izveden znatno manjim kvadrima od onih na južnom ziđu crkve i svetišta, orijentiranim

DEMONJA 2013: 122-124 (s tlocrtom i fotografijama).

9 O produljenju crkve pisano je i ranije. Usp. ŽIC-ROKOV 1977: 277; DEMONJA 1999: 88-90; BRADANOVIĆ 2007: 89-90; Isti 2008: 168.

10 I. FISKOVIĆ 2016: 36, bilj. 70, 44, 71, 116-117, 182, 204. Donosi tlocrt krčke crkve sv. Franje na kojem je grafički raščlanjen produljeni dio od gotičkog (dijelom i ranijeg) sloja.

11 Takav je smještaj, tj. franjevačko preuzimanje benediktinske crkve dobro naslutio već V. Štefanić. Usp. ŠTEFANIĆ 1936: 16-18. Temeljno o povijesnom kontekstu nastanka priorata sv. Ivana usp: JURKOVIĆ 1990: 127-131; Isti 1993: 177-183; Isti 2008: 7-30.

12 Nažalost, radove smo zatekli u poodmakloj fazi pa nismo mogli provesti opsežnije istraživanje primjereno značenju spomenika. Prilikom ograničenog arheološkog nadzora radova R. Starac pronašao je ploču s natpisom utemeljitelja benediktinskoga zdanja. Usp. STARAC 2008: 265268; MATIJEVIĆ-SOKOL 2009: 739-757; BRADANOVIĆ-CIKOVIĆ 2013: 183-196. 
prema unutrašnjosti grada. Ovdje je na crkvenom zidu koji izviruje iznad krovišta klaustra jasno vidljiva i razlika gotičkoga sloga od onog izvedenog većim kvadrima, koji se pruža na produljenju zida prema zapadu. Okolnost da su se franjevci koristili zatečenim benediktinskim zdanjem slična je obližnjem, kasnijem primjeru na krčkom otočiću Košljunu, gdje su ostaci izvorne benediktinske trobrodne crkve konzervatorskim zahvatima u dvama navratima u posljednjih dvadesetak godina otkriveni, dokumentirani, a nedavno dobrim dijelom i prezentirani na sjevernom vanjskom licu zida crkve Navještenja Marijina. ${ }^{13}$ Ta bi okolnost mogla ići u pri$\log$ nešto kasnijoj dataciji (prva polovina 14. stoljeća) jer su se franjevci u Krku najprije mogli koristiti zatečenim benediktinskim crkvenim zdanjem.

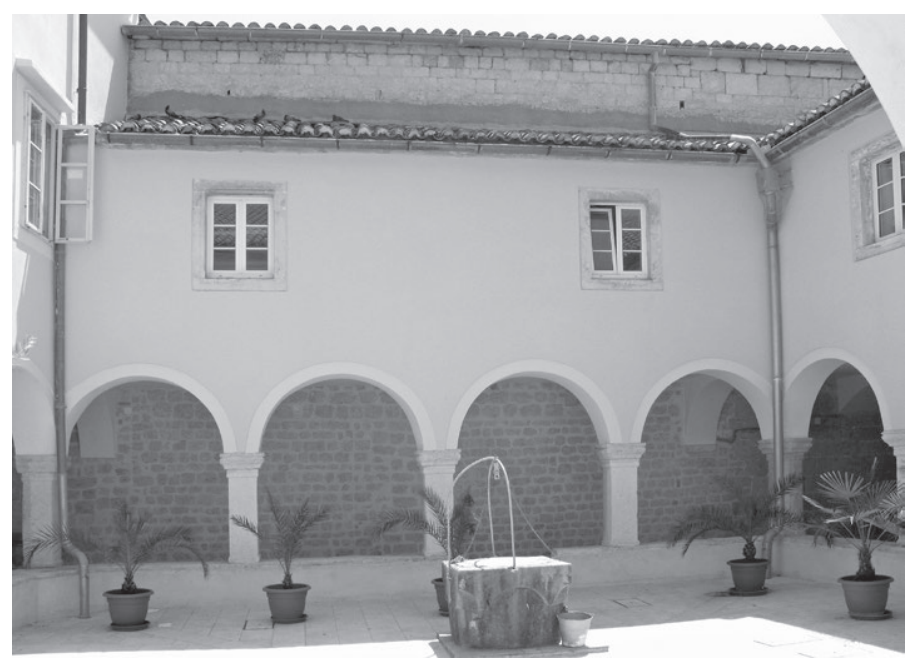

Slika 2: Sjeverni zid crkve sv. Franje u Krku, snimio: D. Krizmanić

Krčku franjevačku crkvu možemo definirati reduciranim regionalnim odvjetkom pulske franjevačke crkve. Pritom ne ističemo samo temeljno arhitektonsko oblikovanje nego i bliskost rješenja dekorativne arhitektonske plastike poput figuralnih konzola u svetištu. ${ }^{14}$ Bila je vjesnicom novoga stila, a njezina je pojava značila promociju pravokutna svetišta svođena križno-rebrastim svodom na otoku Krku, nečeg posve novog u sredini koja je i tijekom ranog 14. stoljeća još uvijek prakticirala konzervativna rješenja s polukružno istaknutim svetištem. ${ }^{15}$ Primjer crkvena

13 GIACONI 1993: 145-150; LIPOVAC-VRKLJAN 1993: 131-144; BRADANOVIĆ 2015: 85-88; Isti 2016a: 5-9.

14 Već citiranu Fiskovićevu tvrdnju o tvrdoći njihova rješenja nijansirali bismo zapažanjem da je riječ o plošnijoj reljefnoj obradi od one s predloška iz pulske crkve sv. Franje. O pulskoj crkvi usp. MARKOVIĆ 2016: 33-53.

15 Usp. JURKOVIĆ 1990: 177-199. 
svetišta nastalog prema uzoru na svetište krčkog Sv. Franje u ruševnom je stanju sačuvan na krčkome Šotoventu pokraj sela Skrpčići. Riječ je o crkvi sv. Nikole „u Grmima“, patricijske obitelji Zuttinis. ${ }^{16} \mathrm{U}$ sakristiji krčke franjevačke crkve sačuvana je vrlo oštećena zidna slika Bogorodice s Djetetom između sv. Ivana i sv. Jurja. ${ }^{17}$ Mišljenja smo da je prostorija tek u 16. stoljeću mogla biti pregrađena i adaptirana za sakristiju, a da je prethodno možda bila dijelom kapitularne dvorane ili neke slične reprezentativne prigradnje. Nad današnjim ulazom u samostan, djelomično prekriven debelim slojem žbuke nalazi se jedan gotički reljef u okviru od izmjeničnih zubaca. Vjerojatno potječe iz 14. ili sa samog početka 15. stoljeća. Figure su na njemu dobro izvedene, a kvalitetom je znatno slabiji prikaz franjevačkog amblema unutar štita. ${ }^{18}$ Zaključno o gotičkoj fazi treba spomenuti podatak o preseljenju oltara sv. Križa iz crkve sv. Franje u katedralu, u vrijeme biskupa Ivana Antuna Šintića. ${ }^{19}$ Primamljivo je razmišljati da je u pitanju bila upravo vrhunska grupa skulpture 14 . stoljeća, prikaz raspela s očuvanim istovremenim likovima Ivana i Marije, ${ }^{20}$ koja se izvorno, prije negoli je ukomponirana u barokni oltar, možda mogla nalaziti upravo na pregradi redovničkoga kora. Zatim je, već kao središnji dio baroknoga oltara, na prijelazu 18. u 19. stoljeće, mogla biti prenesena u katedralnu kapelu sv. Križa, odakle je u novije doba zbog, nažalost, prečestih premještanja katedralnih umjetnina preseljena u središnju apsidu palatinske kapele sv. Kvirina.

Produljenje krčke crkve sv. Franje već ranije smo datirali u doba rane mletačke uprave nad otokom Krkom, zahvat povezujući s mogućim stradanjem crkve prilikom opsade grada koju je 1480. godine provela Korvinova vojska pod zapovjedništvom Blaža Mađara. Radove smo povezali s Ivanom Franjom Bonmartinom, prokuratorom gradnje, 1486. godine sahranjenim na povlaštenom mjestu u crkvenoj lađi. ${ }^{21} \mathrm{U}$ ovom bi kontekstu izvanredno značajan mogao biti dosad nezamijećen podatak koji je iznio Stjepan Ivančić. Radi se o oporuci Elizabete, žene Ivana VII. Mlađeg, posljednjeg frankapanskoga gospodara otoka, kojom je ona 1484. godine krčkim franjevcima ostavila dvije stotine

$\overline{16}$ BRADANOVIĆ 2007 (knjiga II): 140.

17 Prema kazivanju franjevaca, pronašao ju je i od uništenja prilikom zahvata uklanjanja žbuke spasio Anđelko Badurina, a nedavno ju je restaurirao Radovan Oštrić. Freska svakako već pripada franjevačkom sloju korištenja samostanom, a prema mišljenju Željka Bistrovića koji ju je istraživao, može se datirati u prvu polovinu 15. stoljeća.

18 Anđeo nad štitom ima dosta sličnosti u oblikovanju s grbom obitelji Fanfogna iz Narodnog muzeja u Zadru koji je E. Hilje nedavno objavio kao mogući rad Pavla iz Sulmone, no riječ je o standardnom i vrlo čestom trečentističkom modelu oblikovanja, pa je teško donositi čvršće zaključke. Usp. HILJE 2016: 62, 63.

19 IVANČIĆ 1910: 280.

20 Ukratko je na nju, kao vjerojatnom dijelu skupine velikih, jadranskih gotičkih raspela, upozorio J. Belamarić. Usp. BELAMARIĆ 1987: 233, bilj. 79.

21 BRADANOVIĆ 2008: 168.

22 IVANČIĆ 1910: 228. 


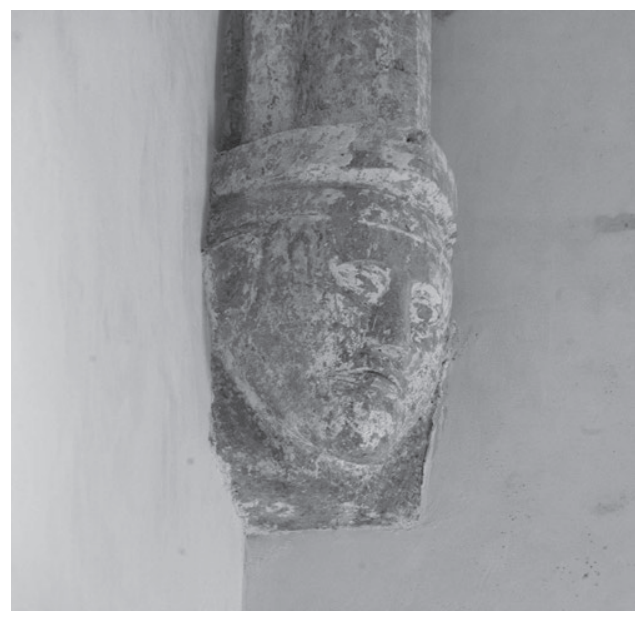

Slika 3: Konzola u svetištu crkve sv. Franje u Krku, snimio: D. Krizmanić

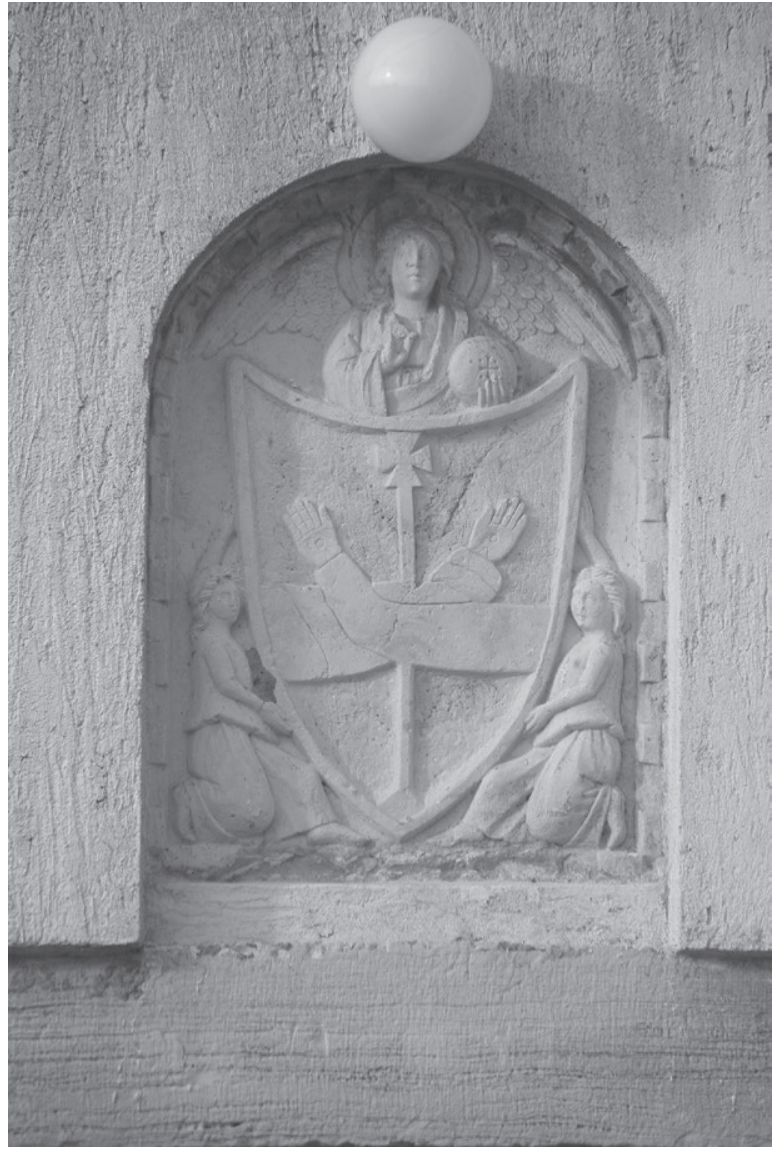

Slika 4: Franjevački grb nad ulazom u samostan sv. Franje u Krku, snimio: D. Krizmanić 
dukata. ${ }^{22}$ Tako je njezin novac možda bio presudan za zahvat produljenja crkve sv. Franje, baš kao što je novac iz oporuke njezine kćeri poslužio velikoj franjevačkoj pregradnji romaničke, nekad benediktinske crkve na Košljunu. ${ }^{23}$ Valja istaknuti da se u inače korektnoj temeljnoj deskripciji krčkog franjevačkog crkvenog zdanja Demonji potkrala pogreška, pri kojoj je reljef mletačkog lava na novom južnom portalu, očito povodeći se za mišljenjem krčkog povjesničara Ivana Žica-Rokova, ${ }^{24}$ proglasio skulpturom 13. stoljeća. Okolnost da je riječ o nadvratniku portala na produljenom dijelu ziđa nastalom nakon 1480. godine pokušao je protumačiti preseljenjem. Mora da ga je pritom zavaralo nespretno klesanje reljefa mletačkog lava. Uz uobičajen raspored prozorskih otvora zapadnog pročelja, koji oblikovanjem oponašaju gotičku fazu gradnje, ovdje je riječ o najvažnijem dekorativnom akcentu produljena dijela crkvene lađe, koji upućuje i na vrijeme kada se zbilo to produljenje. Ipak, ne bismo inzistirali na ovom detalju da Demonja u takvoj dataciji ne ustrajava i u najnovijoj objavi opisa krčke crkve sv. Franje. ${ }^{25}$ Ranije iznesene teze o radovima na produljenju crkve koncem 15. i u ranom 16. stoljeću želimo dopuniti zapažanjem o njihovu nastavku i u trećem desetljeću 16. stoljeća. Nastavljeno je s uređenjem unutrašnjosti, a početkom dvadesetih godina 16 . stoljeća izvedena je nadgrobna ploča Jakova Craie. Zanimljiva je zbog kombiniranja tipično venecijanskih heraldičkih (renesansnih) ornamentalnih rješenja s onima koje Kvarnerom, a osobito Rabom pronose majstori tzv. budimskoga ili Korvinova renesansnog kruga, ponajprije Petar Radov koji se priženio i udomaćio na Rabu ${ }^{26}$ Karakteristične su vijoreće vrpce s perlama na kraju niti. Sličnog je oblikovanja i otprilike istovremenog postanka nadgrobna ploča Franje Mitisa i njegovih potomaka iz 1743. godine, na kojoj je taj Mitisov natpis očito naknadno uklesan. Obje proizlaze iz malog kruga rapskih klesara koji su nastavljali rad Petra Radova.Taj je dio posla na uređenju unutrašnjosti morao biti okrunjen nabavom slike za glavni oltar, što se datira u 1531. godinu. ${ }^{27} \mathrm{~S}$ tim je u vezi vjerojatno bila izvedba velike, sada zazidane, renesansne monofore na južnom zidu svetišta jer je takvu umjetninu dostojno trebalo osvijetliti bočnim svjetlom.

23 VELNIĆ 1966: 69-84; BRADANOVIĆ 2015: 86.

24 ŽIC-ROKOV 1977: 277. Mislio je da je reljef krilatog lava mogao potjecati s izvornog glavnog portala crkve, dakle onoga koji se nalazio na zapadnom pročelju prije produljenja.

25 DEMONJA 2013: 124; Isti 2014: 172. Ne uzimajući pritom u obzir da je već A. Rizzi skulpturu datirao u razdoblje nakon 1480. godine, a M. Bradanović precizirao da je riječ o nevještoj, no ipak jasno renesansnoj skulpturi lava sv. Marka, prikazanog s perspektivno izvedenom aureolom i karakterističnim natpisom, dijelom istovremene serije sličnih, promletačkoga i prikriveno antifrankapanskog karaktera. Rizzi je natpis i objavio. Usp. RIZZI 2001: 252; BRADANOVIĆ 2008: 168, 178, bilj. 5. 


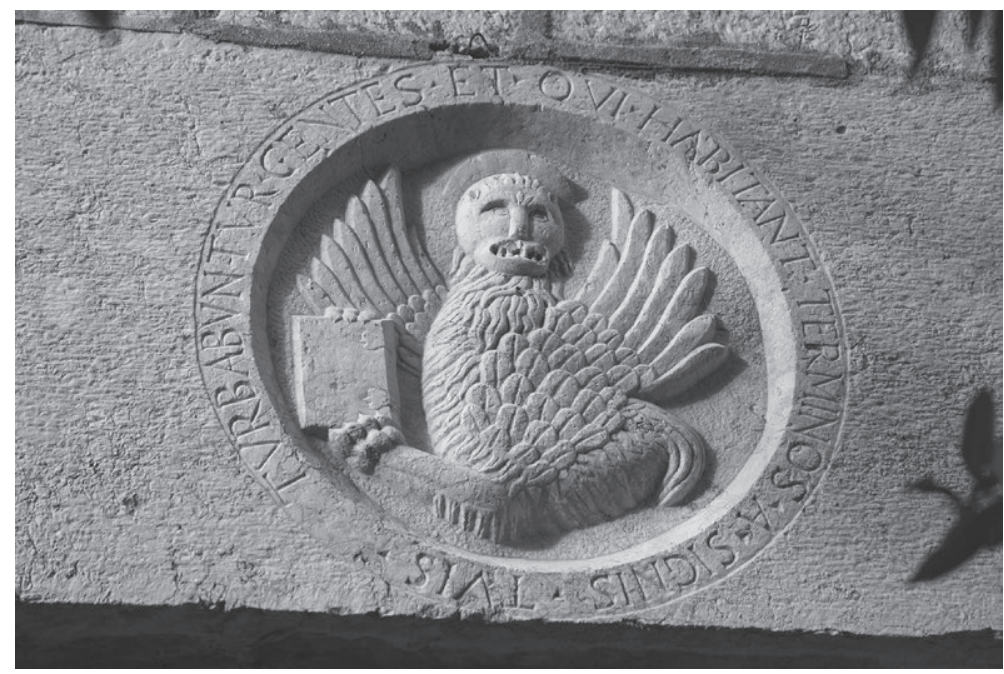

Slika 5: Reljef lava sv. Marka na nadvratniku portala produljenog dijela južnog zida crkve sv. Franje u Krku, snimio D. Krizmanić

Radovi su se zatim mogli nastaviti izvedbom robusnog zvonika oblikovanoga na način karakterističan za lokalne radionice $u$ doba visoke renesanse na otoku Krku. Zvonik raščlanjen kamenim kordonskim vijencima ima jednostavne, danas dijelom zazidane monofore i bifore, ukrašene skromno izvedenom dekorativnom plastikom kapitela s palmetnim listovima i volutama te konzolama u obliku lavljih glavica. Dio toga materijala ondje je sekundarno dospio. Ponešto sličnosti oblikovanja otvora dijeli sa zvonikom omišaljske zborne crkve iz 1536. godine, iako je ondje riječ o još rustičnijoj realizaciji. Dekorativnoj plastici zvonika bliski su reljefi sakristijskog pila crkve sv. Franje, a na radove istih majstora nailazimo i na pročeljima krčkih gradskih kuća.

Da se s radovima uređenja samostana nastavilo u kontinuitetu svjedoči 1625 . godina, uklesana u medaljonu na jednom od stupaca skladnoga klaustra. ${ }^{28} \mathrm{~S}$ tim razdobljem valja povezati i dio profilacije kamenoga gređa samostanskih prozorskih otvora, danas najvećim dijelom u sekundarnoj poziciji ugrađenih u kasnije okvire svijetlih otvora. Očito je do znatnijega uređenja samostana smještenoga tik uz gradske zidine moglo doći tek nakon što je minula ratna opasnost iz doba Uskočkoga rata, iako Žic-Rokov donosi podatak da su već 1500. godine mletačke vlasti franjevcima odobrile prozorske otvore na gradskim zidinama. ${ }^{29}$ Unatoč

$\overline{28}$ Kasnih devedesetih godina 20. stoljeća zatekli smo ga u spomeničkom smislu degradiranoga, naknadnim ispunama izvedenim početkom toga stoljeća, negiranih lukova i razdijeljenoga na niz malih prostora. Uvelike zakašnjelim konzervatorskim zahvatom, ponajprije zahvaljujući razumijevanju trećoredaca, uspjeli smo barem dijelom vratiti izvorno oblikovanje klaustra, iako je projekt prema kojem se izvodio opsežni zahvat adaptacije bio daleko od konzervatorskih uzanci postupanja. 
velikim radovima pregradnji i adaptacija vršenih 1910. i koncem devedesetih godina 20. stoljeća, koji, nažalost, nisu popraćeni adekvatnim konzervatorskim nadzorom, i danas su u strukturama samostana dobro vidljivi dijelovi sjevernih gradskih zidina. Ono što je u elevaciji sačuvano, osobito u smislu otvora za vatreno oružje, mahom se može datirati u 16. stoljeće, a na sjeverozapadnom rubu obzidanoga grada, podno franjevačkog vrta, nalazi se poznati ostatak antičkog bedema datiran $\mathrm{u}$ ranocarsko razdoblje. ${ }^{30}$

\section{Trećoredski samostan i crkva sv. Frane na Komrčaru}

Samostan i jednobrodna crkva lađe te pravokutna svetišta svođenih šiljastobačvastim svodom smješteni su na Komrčaru, nadomak gradskih zidina. Riječ je o istaknutome mjestu, na uzvisini između dna poluotoka s obzidanim gradom i predjela Palit bogatog vodotocima koji su utjecali u uvalu u kojoj se u novom vijeku nalazio škver. Franjevci su i ranije boravili na ovom predjelu koji je i tijekom ranijih stoljeća imao ulogu u gospodarstvu grada Raba. ${ }^{31} \mathrm{U}$ širem topografskom zahvatu možemo zaključiti da je trećoredski samostan zauzimao prostor između gradskih zidina i područja koje je pripadalo kamporskom franjevačkom samostanu sv. Eufemije. Rapsko zanatsko predgrađe Varoš ili Borgo, razvijano u ranom novom vijeku, prostiralo se duž Rapskog zaljeva, od glavnih gradskih vrata prema podnožju brijega na kojem se nalazio trećoredski samostan. Stoga je on, poput slučaja trećoredskog Bijara nadomak Osora, kao i njihovih istarskih samostana nadomak novigradskih i koparskih zidina, a posve suprotno od creske Martinšćice te krčkih Glavotoka i Porta kao izrazito ladanjskih lokaliteta, imao svojevrsni prigradski karakter. Pritom je važno istaknuti da je samostan bio središtem projekta širenja trećoredskih samostana na Kvarnerskim otocima, pothvata koji je iznimnom energijom vodio vrlo sposobni fra Matej Mastilić iz Zadra. Nakon duga života i ostvarenja svojih ciljeva ondje je na Komrčaru i pokopan. Fra Matej iz Zadra na Komrčaru je preuzeo već postojeći hospital sv. Katarine i istoimenu crkvu koja se pokraj njega nalazila. Taj je lokalitet već služio kao utočište redovnika pustinjaka. Oni su često bili doseljenici iz unutrašnjosti, Like i Bosne, izbjeglice pred osmanskim prodorima, sasvim u skladu s dinamičnom etničkom slikom otočne zajednice druge polovine 15 . stoljeća kao utočišta u nemirnim vremenima, koju je izvrsno opisao Dušan Mlacović. ${ }^{32} \mathrm{Na}$ takve doseljenike kao redovnike mletačke su vlasti prijeko gledale, tako da je fra Matej vjerojatno po-

\footnotetext{
30 MARGETIĆ 1987: 171-183; BRADANOVIĆ 2016b: 6.

31 Usp. BRUSIĆ 1920: 172-173 (spominje i antičke nalaze). Prevladava mišljenje da naziv predjela dolazi od comercarius, tj. naziva za gradskog službenika u trgovini solju. Usp. SKOK 1950: 61; BUDAK 2006: 131-132; MLACOVIĆ 2008: 170.

MLACOVIĆ 2008: 99-110; RUNJE 1987: 333-336.
} 
stao idealna spona između došljaka iz krajeva iz kojih je sam poticao i mletačkih vlasti čije je povjerenje zadobio, i to ne samo stoga jer je bio građaninom Zadra. Podaci iz biografije koju su pažljivo rekonstruirali povjesničari trećoredaca upućuju na izvanrednu osobnost dinamična čovjeka, sveprisutnoga na području od Zadra prema otocima sjeverne Dalmacije, a ponekad i šire, usporedivu s nekim fratrima - graditeljima našega doba. O njegovu ugledu svjedoče punomoći koje je za složene funkcije i osjetljive poslove u turbulentna vremena lako dobivao, kao i dopuštenja za preuzimanje crkava i gradnju samostana koja je, čini se, s lakoćom uspijevao ishoditi. ${ }^{33}$

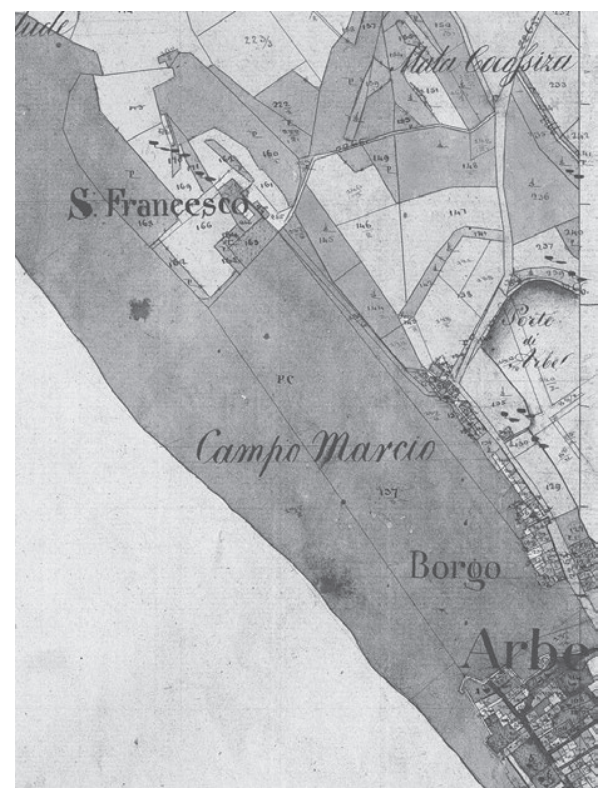

Slika 6: Odnos grada Raba, gradskoga podgrađa i samostana sv. Frane na Komrčaru na katastarskoj mapi 1828. godine

Nova crkva na Komrčaru, građena na prijelazu osamdesetih u devedesete godine 15. stoljeća, položena je s unutarnje, sjeverne strane samostana, duž njegova sjeveroistočna krila, suprotno od samostanske jugozapadne fasade orijentirane prema Kam-

33 Primjerice, Runje navodi fra Matejevo imenovanje prokuratorom trećoredske provincije 1473. godine, funkciju na koju ga je postavio provincijal franjevaca trećoredaca, zatim godinu kasnije njegovo svjedočenje jednoj osorskoj oporuci u korist trećoredaca, a idućih godina nalazi ga u Rabu i češće u Zadru, već kao provincijala. U posjed Komrčara uveo ga je rapski knez, a crkvu na Bijaru, uz kasniju papinu potvrdu, predaje mu osorski biskup Palčić. Godine 1493. general franjevačkog reda Sansoni imenuje ga povjerenikom za Dalmaciju. Iduće godine tadašnji ga provincijal opunomoćuje za pravne poslove u Rimu i Veneciji. Spominjemo ovo kao dio njegove djelatnosti u godinama kada je često bio u pokretu. RUNJE 1985: 107-118. Usp. IVANČIĆ 1910: 163-167. 
porskom zaljevu. Ugovor o njezinoj gradnji, koji su 1490. godine potpisali trećoredac Blaž i majstor Petar (magistro Petro lapicida), objavio je Cvito Fisković. ${ }^{34}$ Predstavlja jedan od važnijih dokumenata o renesansnoj arhitekturi Kvarnerskih otoka.

Kao važan primjer renesansne arhitekture Kvarnera crkva je primjereno valorizirana u temeljnim nacionalnim, renesansi posvećenim povijesno-umjetničkim sintezama $^{35}$, kao i u monografijama koje se odnose na baštinu grada i otoka Raba. ${ }^{36}$ Demonja je donio pregled prethodnih istraživanja, iscrpan opis vanjštine i vrlo sumaran, pa i nedovoljan opis crkvene unutrašnjosti, s obzirom na njezino značenje u cjelovitom sagledavanju važnosti ovog spomenika. U valorizaciji se u ovom slučaju posve oslonio na Ivančevićev rad o renesansnim crkvama trolisnih pročelja. ${ }^{37}$

Zanimljivu je pretpostavku iznio Igor Fisković. U odlomcima svoje sinteze o franjevačkoj arhitekturi na istočnoj obali Jadrana, posvećenima mogućem udjelu franjevaca u projektiranju i gradnji crkava, vrlo oprezno, no ipak kao najizvjesniji takav slučaj naglasio je mogući projektantski udio fra Mateja iz Zadra u gradnji crkve sv. Frane na Komrčaru. Pozivao se pritom na Ivančićeve podatke o fra Mateju, koji je „vlastoručno gradio i popravljao njihove crkve na Kvarneru“, sve argumentirajući okolnošću da je takva ,jednostavna“ crkva u „dimenzijama bila savladiva za jednog graditelja“. U nastavku teksta naglasio je općenitu rezervu prema razmišljanju o franjevcima kao projektantima crkava, ne odričući se mogućnosti njihova udjela u pojedinim zanatskim poslovima ${ }^{38}$, a upravo u takvom kontekstu i mi vidimo graditeljske pothvate trećoredaca na Kvarneru, osobito u kasnijem razdoblju 16. stoljeća i osobito na ladanju, gdje je trećoredska glagoljaška kultura činila jedinstveno i skladno tijelo s okolnim ruralnim zajednicama. Iako je Fisković posve u pravu, u pogledu jednostavnosti temeljnog arhitektonskog oblikovanja komrčarske crkve, sam njezin odabir kao cjelovitog arhitektonskog ostvarenja u tom kontekstu čini nam se donekle neprimjerenim, pogotovo u usporedbi s kasnijim trećoredskim realizacijama na Kvarneru jer njezin dekorativni repertoar otkriva znatno veće ambicije i složenost zahvata, kao i kompetencije svih njegovih realizatora. Projektantski udio fra Matije vjerojatno nikad nećemo preciznije utvrditi, no s obzirom na značenje koje je pridavao izgradnji na Komrčaru i cjelinu njegova karaktera koja izvire iz pisanih izvora, kao i radijus kojim

\footnotetext{
34 C. FISKOVIĆ 1987: 326-328.

I. FISKOVIĆ 2016: 195-199. U pogledu fra Matijina udjela u gradnji Ivančić je, uz isticanje razumljive sličnosti arhitektonskih rješenja trećoredskih samostana na Kvarneru, htio naglasiti kako je „on sam vlastitim rukama pomagao zidati crkve i samostane“. IVANČIĆ 1910: 40. Naglasak je bio na praksi fizičkog rada, i danas vrlo izraženoj kod trećoredaca i opservanata, a, naravno, i na revnosti i poduzetnosti fra Matije Mastilića Zadranina, ponekad zvanog Ručica. Usp. RUNJE 1985: 110.
} 
se kretao između Zadra, Raba i Osora, pa i prema Veneciji, možemo slutiti da je njegov udio u primijenjenim dekorativnim rješenjima i odabiru majstora klesara koji su ih izvršavali vjerojatno bio popriličan.

Uz osorsku katedralu i cresku zbornu crkvu, upravo je komrčarska crkva najdosljedniji primjer implementacije all'antica dekorativnih elemenata u ukupnoj arhitekturi Kvarnerskih otoka. Dojam bi vjerojatno bio i naglašeniji da nije bilo baroknih preinaka, a i da u ambicioznim restauratorskim pothvatima 19. i ranog 20. stoljeća nije došlo do preslagivanja crkvenog pročelja. Osim višestruko analizirana pročelja na kojem je, uz upravo na Rabu očekivani utjecaj budimskoga kruga klesara proizišlih iz toskanske renesansne tradicije, odavno zamijećen i utjecaj venecijanske renesanse, ${ }^{39}$ posvetimo u tom kontekstu nekoliko riječi dosad nedovoljno analiziranoj unutrašnjosti crkve. Na licu pilastara trijumfalnog luka od rumene rapske breče nalaze se medaljoni s reljefnim prikazima franjevačkoga grba i grba lateranske bazilike. Na bočnim stranicama pilastara trijumfalnog luka oni imaju ekvivalent u vidu plemićkih grbova. Grbovi rapskoga patricijata nižu se i duž intradosa trijumfalnog luka. Dok su franjevački i lateranski grb izvedeni unutar jednostavnih medaljona, tj. kružnica obrubljenih plitkim, renesansnim torusnim profilom, grbovi mjesnoga plemstva izvedeni su u gotičkom obliku „konjske glave“ s pobočno pridodanim karakterističnim vijorećim vrpcama ili bez njih. Svaki od reljefnih prikaza s intradosa na licu trijumfalnog luka ima svog parnjaka u vidu praznog (nekad možda oslikanog?) medaljona lica trijumfalnog luka. Bez sumnje, riječ je o artikuliranom projektu koji je podupirao najistaknutiji dio rapskoga patricijata, ljudi okrenutih pomorstvu i trgovini.

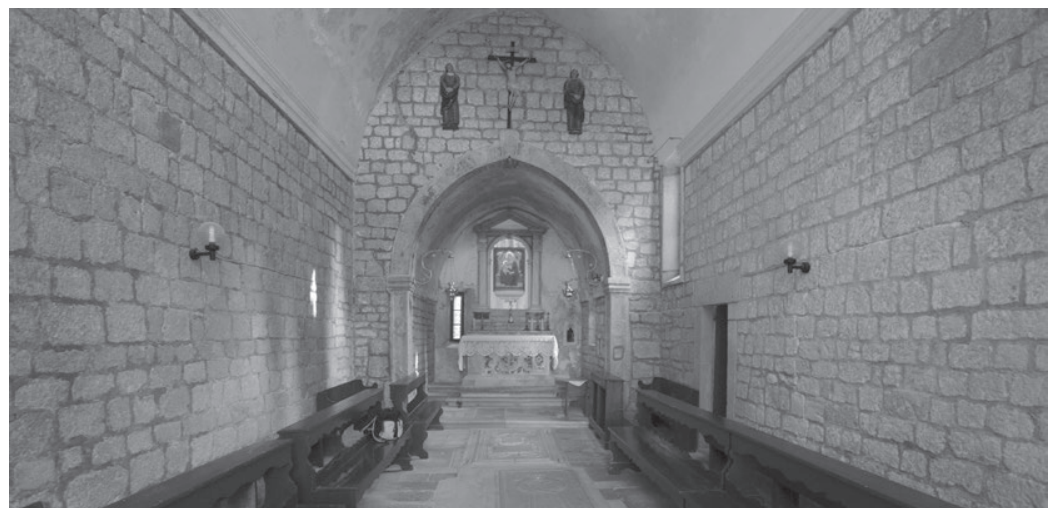

Slika 7: Unutrašnjost crkve sv. Frane na Komrčaru, snimio D. Krizmanić

39 Usp. C. FISKOVIĆ 1987: 321-332 (izvrsno ističući „budimske“, tj. toskanske i venecijanske elemente oblikovanja pročelja); IVANČEVIĆ 1992-93: 113-114 (komparativno analizirajući venecijanski element oblikovanja); I. FISKOVIĆ 2000: 68-82 (ističući vrsnoću vijenca nad portalom komrčarske crkve i tražeći autorstvo među akterima budimskoga kruga renesansnih majstora); MARKOVIĆ 2004: 99-100; BRADANOVIĆ 2008: 179, bilj. 19. 


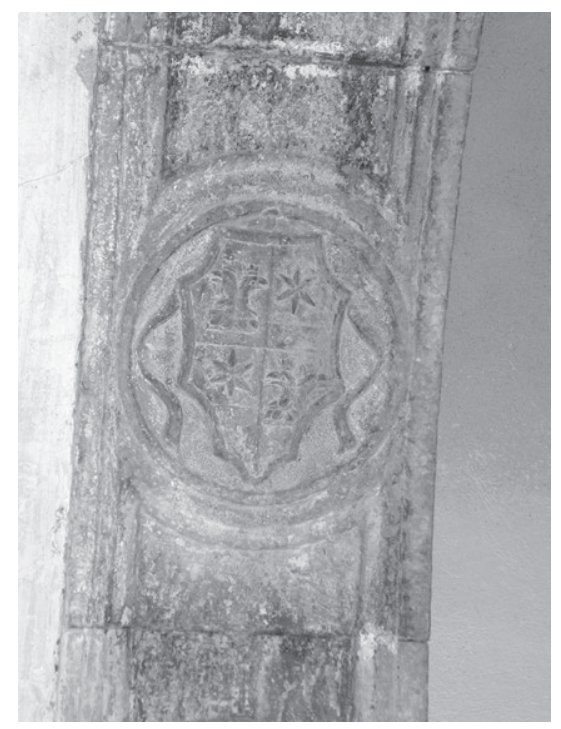

Slika 8: Grb obitelji Dominis na trijumfalnom luku crkve sv. Frane na Komrčaru, snimio D. Krizmanić

Tik pred svetištem, na mjestu rezerviranom za iznimno važna donatora, nalazi se grobna raka rapskoga slikara Juana Boschetusa iz 1515. godine. ${ }^{40}$ Ploča je izvrstan i za rapske prilike vrlo složen primjer onoga što se naziva ornamentalnim repertoarom ugarske renesanse. Na sredini svake stranice vegetabilne bordure okvira ploče uklesan je pokojnikov monogram. Na središnjem je štitu, obrubljenom lovorovim vijencem, prikazana piramida, njezin odraz i sunce. Iz ljiljana nad štitom izviru nabrane vijoreće vrpce povijenih krajeva. Podno štita na plitkim vrpcama ovješena je tabula ansata s natpisom o pokojniku. ${ }^{41}$ Odmah iza Bosche-

40 SCHLEYER 2014: 121; C. FISKOVIĆ 1987: 331; DOMIJAN 2001: 208.

${ }^{41}$ Ovakvo je rješenje impostacije i izvedbe reljefa u reduciranoj i dosta nespretnijoj inačici imitirano u crkvi sv. Ivana Krstitelja, tadašnjoj zbornoj crkvi bašćanskog kaštela. Usp. SOBOTA-MATEJČIĆ 2008: 107-114. Pritom treba naglasiti da su naručitelju i izvoditelju komrčarske nadgrobne ploče pred očima bili u Rabu brojni, kasnije nestali uzori poput impostacija nadgrobne ploče biskupa Zudeniga u katedrali ili one Petra Zara u kamporskoj franjevačkoj crkvi sv. Bernardina. Zanimljivo je primijetiti da se na Boschetusovoj nadgrobnoj ploči, koju je Domijan pripisao tad već ostarjelom Petru Radovu, pojavljuje čitav niz novih elemenata, inače bliskih ugarskim renesansnim majstorima poput Johannesa Fiorentinusa (npr. od našeg rapskog primjera godinu dana mlađi reljef nadgrobne ploče biskupa Jana Laskija iz Gniezna koji donosi Pelc). Kako Pelc ističe, iza imena stajala je radionica oscilirajuće kvalitete, pa je možda u našem slučaju ipak riječ o nekom došljaku koji se kretao već znanim stazama iz Ugarske prema Rabu. Usp. PELC 2006: 69. Zanimljivo je i to da ova nadgrobna ploča stoji u ishodištu većeg broja nadgrobnica slabije kvalitete koje su nju, a možda i neki drugi izgubljeni spomenik imitirale, a nalazimo ih na užem regionalnom području od Paga do Krka. 


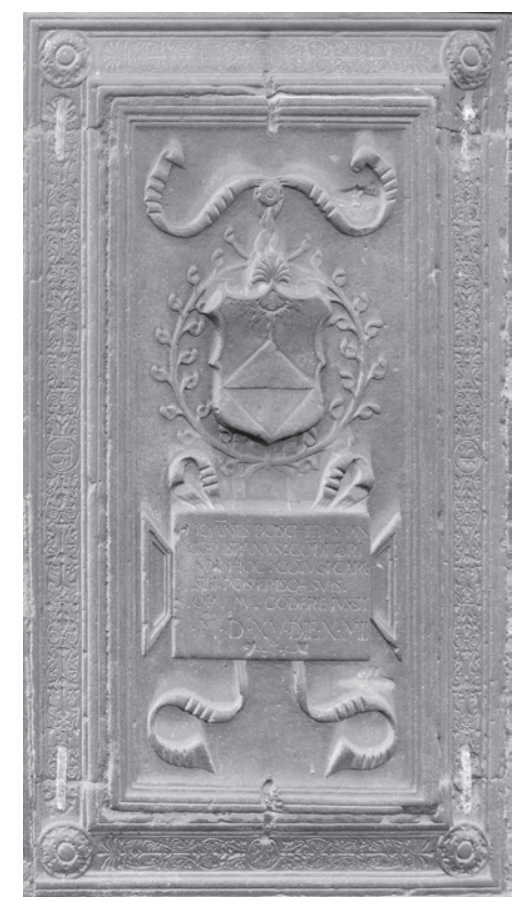

Slika 9: Nadgrobna ploča Juana Boschetusa pred svetištem crkve sv. Frana na Komrčaru, snimio D. Krizmanić

tusove, dublje u lađi pruža se nadgrobna ploča nad rakom za koju se drži da u njoj počiva tijelo fra Matije Mastilića iz Zadra. ${ }^{42}$ Riječ je o slabijem radu, izvedenom u plitkom reljefu, ponegdje tek rudimentarno naznačenih detalja. Ipak, bosonogom je fratru posebno priznanje odano prikazom cjelovitog lika, na način uobičajen za nadgrobne ploče biskupa ili istaknutih članova kanoničkog zbora katedrale. Fratrima kao naručiteljima, a i klesaru izvoditelju zacijelo su temeljnim uzorom bile sasvim konkretne rapske nadgrobne ploče biskupa Zudeniga i Scaffe. Dalje prema pročelju nalazi se nadgrobna ploča s prikazom tesarskoga alata, senjskoga kalafata Mrganića iz 1558. godine. ${ }^{43}$

Dijelovi samostanske gradnje tek su fragmentarno sačuvani u pratećim građevinama groblja, čijim je smještajem zapečaćena sudbina samostanske arhitekture. Srećom je prije potpunog rušenja samostana izvršeno arhitektonsko dokumentiranje već ruševnoga sklopa. ${ }^{44}$ Ističu se stupci i lukovi koji su nekad pripadali

\footnotetext{
42 Datirana je u 1525. godinu glagoljskom datacijom uklesanom duž gornjeg ruba jastuka na kojem počiva pokojnikova glava, pa se ta godina drži i godinom Mastilićeve smrti. Usp. FUČIĆ 1982: 296.

43 SCHLEYER 2014: 122; DOMIJAN 2001: 207.

44 SCHLEYER 2014: 118-121.
} 
klaustru, a sada čine dijelove trijema mrtvačnice. ${ }^{45} \mathrm{Na}$ slojevitost lokaliteta upućuje i nepravilni odnos crkve i dijelova samostana jer je dvorište s cisternom smješteno dijagonalno u odnosu na pročelje crkve. Sama cisterna nije centrirana u središtu dvorišta. Unatoč tome, kao što je sama crkva sv. Frane poslužila kao prototip trećoredskoj arhitekturi koja je uslijedila na Kvarneru, vjerojatno su se tako detalji oblikovanja renesansnog samostana, poput male kvadratično koncipirane cisterne, za koju izvori navode da ju je gradio sam fra Matej, imitirali u kasnijim trećoredskim gradnjama. Ivančić spominje 1657. uklesanu na portalu samostana, ispravno je tumačeći godinom koja je bilježila neki popravak i dogradnju samostana jer je, prema sačuvanoj kamenoj građi i povijesnoj fotografiji, središnje dijelove klaustra moguće datirati u 16. stoljeće. ${ }^{46}$

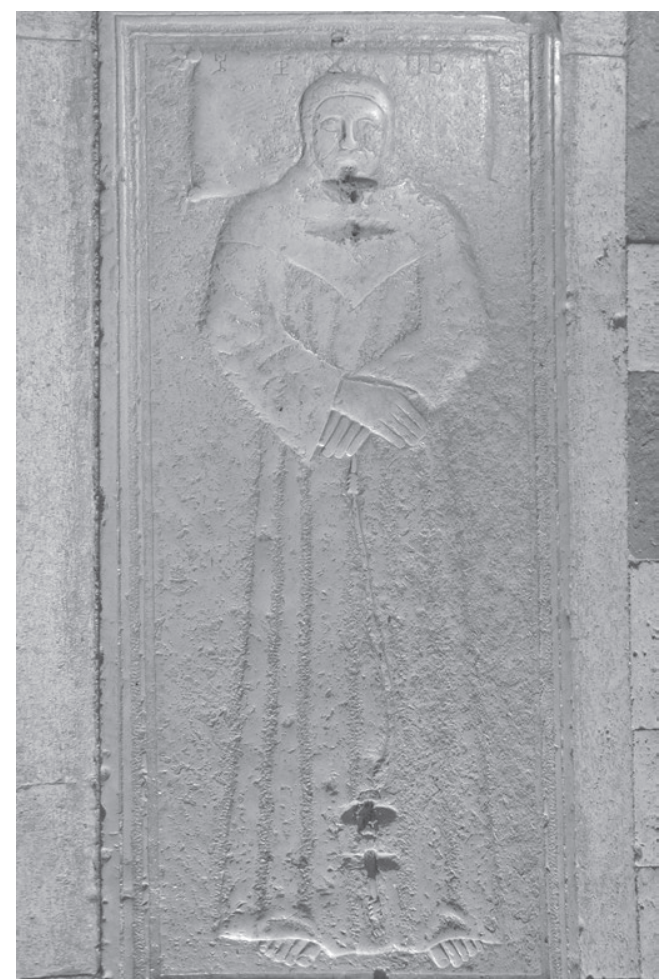

Slika 10: Vjerojatna nadgrobna ploča fra

Mateja iz Zadra, snimio D. Krizmanić

45 DOMIJAN 2001: 203.

46 IVANČIĆ 1910: 288-289; RUNJE 1985: 107-118. 


\section{Bibliografija}

BELAMARIĆ, Joško. 1987. Gotičko raspelo iz Kotora. Prilozi povijesti umjetnosti u Dalmaciji 26: 217-261.

BOLONIĆ, Mihovil, Ivan ŽIC ROKOV. 1977. Otok Krk kroz vjekove. Zagreb: Kršćanska sadašnjost.

BRADANOVIĆ, Marijan. 2007. Arhitektura i urbanizam renesanse na otoku Krku. Doktorski rad, Sveučilište u Zadru, Odjel za povijest umjetnosti.

BRADANOVIĆ, Marijan. 2008. Prvi krčki renesansni klesari. U Renesansa i renesanse u umjetnosti Hrvatske. Zbornik radova sa znanstvenih skupova ,Dani cvita Fiskovića “ održanih 2003. i 2004., ur. Predrag Marković, Jasenka Gudelj, 167-182. Zagreb: Institut za povijest umjetnosti, Odsjek za povijest umjetnosti Filozofskog fakulteta Sveučilišta u Zagrebu.

BRADANOVIĆ, Marijan. 2011. Graditeljstvo Dubašnice u razdoblju renesanse. U „,Az grišni diak Branko pridivkom Fučič", Radovi međunarodnoga znanstvenog skupa o životu i djelu akademika Branka Fučića (1920.-1999.), ur. Tomislav Galović, 231-258. Malinska-Rijeka-Zagreb: Hrvatska akademija znanosti i umjetnosti, Institut za povijest umjetnosti, Katolički bogoslovni fakultet Sveučilišta u Zagrebu, Staroslavenski institut, Sveučilišna knjižnica Rijeka, Općina Malinska-Dubašnica.

BRADANOVIĆ, Marijan. 2012. Rab i recepcija renesanse u arhitekturi i skulpturi na sjevernom Jadranu. Rapski zbornik II: 451-459.

BRADANOVIĆ, Marijan. 2015. Franjevačka graditeljska aktivnost na Kvarneru, u Hrvatskom primorju i njegovu zaleđu tijekom 15. i 16. stoljeća. U Nastanak zapadnohrvatske franjevačke pokrajine Bosne-Hrvatske prije 500 godina, ur. Franjo Emanuel Hoško, 77-90. Rijeka: Franjevački samostan na Trsatu, Naklada Kvarner.

BRADANOVIĆ, Marijan. 2016a. Otok Krk u srednjem vijeku. Split: Muzej hrvatskih arheoloških spomenika.

BRADANOVIĆ, Marijan. 2016b. Grad Krk u srednjem vijeku. Split: Muzej hrvatskih arheoloških spomenika.

BRADANOVIĆ, Marijan, Danijel CIKOVIĆ. 2013. The Church of St. Lawrence outside the Town Walls of Krk. Hortus Artium Medievalium 19: 183-196.

BRUSIĆ, Vladislav. 1920. Otok Rab. Rab: Franjevački samostan sv. Eufemije.

BUDAK, Neven. 2006. Urban Development of Rab - a Hypothesis. Hortus artium medievalium 12: 123-135.

DEMONJA, Damir. 1999. Franjevačke crkve na hrvatskoj obali do kraja 16. stoljeća. Doktorska disertacija, Filozofski fakultet Sveučilišta u Zagrebu.

DEMONJA, Damir. 2013. Franjevačke crkve na hrvatskoj obali Jadrana do kraja 16. stoljeća. Zagreb: Vedis.

DEMONJA, Damir. 2014. Prilog proučavanju tipologije franjevačkih crkava u Istri i na otocima Kvarnerskog zaljeva. Histria archaeologica 45: 159-200.

DOMIJAN, Miljenko. 2001. Rab: Grad umjetnosti. Zagreb: Barbat. 
FISKOVIĆ, Cvito. 1987. Prilog poznavanju kiparstva i graditeljstva 15. i 16. stoljeća u Rabu. Rapski zbornik I: 321-332.

FISKOVIĆ, Igor. 2000. Jadranska Hrvatska - Ugarska kralja Matije Korvina. U Hrvatska-Mađarska-Europa, ur. Jadranka Damjanov, 68-82. Zagreb: Društvo mađarskih znanstvenika i umjetnika u Hrvatskoj.

FISKOVIĆ, Igor. 2016. Secundum morem patriae: identitet crkava propovjedničkih redova u jadranskoj Hrvatskoj. Zagreb: Društvo povjesničara umjetnosti.

FUČIĆ, Branko. 1982. Glagoljski natpisi. Zagreb: Jugoslavenska akademija znanosti i umjetnosti, Razred za filologiju i Razred za likovne umjetnosti.

GIACONI, Hrvoje. 1993. Prikaz prijedloga idealne rekonstrukcije tlocrta crkve sv. Marije benediktinske opatije na Košljunu. U Umjetnost na istočnoj obali Jadrana u kontekstu europske tradicije, ur. Nina Kudiš, Marina Vicelja [Posebno izdanje Zbornika Pedagoškog fakulteta], 145-150. Rijeka: Pedagoški fakultet, Rijeka.

HILJE, Emil. 2016. Zadarski kipar i graditelj Pavao Vanucijev iz Sulmone. Zadar: Sveučilište u Zadru.

IVANČEVIĆ, Radovan. 1992-1993. Trolisna pročelja renesansnih crkava u Hrvatskoj. Peristil 35-36: 85-120.

IVANČIĆ, Stjepan. 1910. Povjestne crte samostanskom III. Redu sv. O. Franje po Dalmaciji, Kvarneru i Istri i poraba glagolice u istoj redodržavi sa prilozima. Zadar: Odlikovana tiskarna E. Vitaliani.

JURKOVIĆ, Miljenko. 1990. Romanička sakralna arhitektura na gornjojadranskim otocima. Doktorska disertacija, Filozofski fakultet Sveučilišta u Zagrebu, Odsjek za povijest umjetnosti.

JURKOVIĆ, Miljenko. 1993. Uloga Zadra, Clunya i kneževa Frankopana u promociji romanike na otoku Krku. U Umjetnost na istočnoj obali Jadrana u kontekstu europske tradicije, ur. Nina Kudiš, Marina Vicelja [Posebno izdanje Zbornika Pedagoškog fakulteta], 177-183. Rijeka: Pedagoški fakultet, Rijeka.

JURKOVIĆ, Miljenko. 2008. Benediktinci na sjevernom Jadranu. U Opatijske crkvene obljetnice - Zbornik radova sa znanstvenog skupa održanog u Opatiji 17. i 18. studenog 2006. godine, ur. Goran Crnković, 7-30. Opatija: Grad Opatija, Rezidencija DI u Opatiji, Župa sv. Jakova.

LIPOVAC-VRKLJAN, Goranka. 1993. Zaštitna arheološka istraživanja samostanske franjevačke crkve Navještenja Blažene Djevice Marije na Košljunu. U Umjetnost na istočnoj obali Jadrana u kontekstu europske tradicije, ur. Nina Kudiš, Marina Vicelja [Posebno izdanje Zbornika Pedagoškog fakulteta], 131-144. Rijeka: Pedagoški fakultet, Rijeka.

MARGETIĆ, Lujo. 1987. O natpisu o gradnji krčkih gradskih bedema sredinom 1. st. pr. n. e. Arheološki radovi i rasprave 10: 171-183.

MARKOVIĆ, Predrag. 2004. Arhitektura renesanse u Hrvatskoj. U Hrvatska renesansa, ur. Miljenko Jurković, Alaine Erlande-Brandenburg, 71-110. Zagreb: Galerija Klovićevi dvori.

MARKOVIĆ, Predrag. 2016. Crkva sv. Franje Asiškog u Puli - lokalno, regionalno i internacionalno. U Razmjena umjetničkih iskustava u jadranskom bazenu, Zbornik 
radova znanstvenog skupa „Dani Cvita Fiskovića“ VI. održanog 2014., ur. Predrag Marković, Jasenka Gudelj, 33-53. Zagreb: Sveučilište u Zagrebu, Filozofski fakultet, Odsjek za povijest umjetnosti.

MATIJEVIĆ-SOKOL, Mirjana. 2009. Latinska epigrafija otoka Krka od od 9. do 12. stoljeća. Prilog kontekstualizaciji novopronađenog natpisa u gradu Krku. U „Az grišni diak Branko pridivkom Fučić", Radovi međunarodnoga znanstvenog skupa o životu i djelu akademika Branka Fučića (1920.-1999.), ur. Tomislav Galović, 739-757. Malinska-Rijeka-Zagreb: Hrvatska akademija znanosti i umjetnosti, Institut za povijest umjetnosti, Katolički bogoslovni fakultet Sveučilišta u Zagrebu, Staroslavenski institut, Sveučilišna knjižnica Rijeka, Općina Malinska-Dubašnica.

MLACOVIĆ, Dušan. 2008. Građani plemići: pad i uspon rapskoga plemstva. Zagreb: Leykam international.

PELC, Milan. 2006. Ugarske kiparske radionice i renesansa u sjevernoj Hrvatskoj. Radovi Insituta za povijest umjetnosti 30: 67-80.

PELC, Milan. 2007. Renesansa. Zagreb: Naklada Ljevak.

RIZZI, Alberto. 2001. I leoni di San Marco. Il simbolo della Repubblica Veneta nella scultura e nella pittura. Volume secondo. Catalogo. Venezia: Arsenale Editrice-Regione del Veneto.

RUNJE, Petar. 1985. Novi prilozi za život o. Mateja Bošnjaka-Mastilića franjevca trećoreca (o. 1430-1525.). Croatica Christiana Periodica 9/16:107-118.

RUNJE, Petar. 1987. Franjevci trećoreci-glagoljaši na Rabu u srednjem vijeku. Rapski zbornik I: 333-337.

SCHLEYER, Wilhelm. 2014. Arbe: Stadt und Insel, ein Schatzkästleinder Natur und Kunst in Dalmatien. Wiesbaden: C.W. Kreidel's Verlag.

SKOK, Petar. 1950. Slavenstvo i romanstvo na jadranskim otocima: Toponomastička ispitivanja. Zagreb: Jadranski institut Jugoslavenske akademije znanosti i umjetnosti.

SOBOTA-MATEJČIĆ, Gordana. 2008. Pala sveti razgovor iz Baške. Radovi Instituta za povijest umjetnosti 32: 107-114.

SOBOTA-MATEJČIĆ, Gordana. 2012. Bernardino Licinio. U Tizian-Tintoretto-Veronese. Veliki majstori renesanse, ur. Radoslav Tomić, 170-173. Zagreb: Galerija Klovićevi dvori.

STARAC, Ranko. 2008. A contibution toward the better understanding of twelfth-century epigrafic monuments in the town of Krk. Hortus artium medievalium 14: 265-268.

ŠTEFANIĆ, Vjekoslav. 1936. Opatija sv. Lucije u Baški i drugi benediktinski samostani na otoku Krku. Croatia Sacra. Arkiv za crkvenu povijest Hrvata 6: 1-86.

VELNIĆ, Teofil. 1966. Košljun kod Punta na otoku Krku. Zadar-Pazin: Franjevački provincijalat Zadar, Biskupski ordinarijat Pazin.

ŽIC-ROKOV, Ivan. 1971. Gradske ulice i trgovi u Krku. Krčki zbornik 2: 179-255. 


\section{Architectural Heritage of Franciscan Tertiaries on Kvarner Islands (Part 1)}

The string of Tertiary monasteries on the islands in the Kvarner Gulf, reflecting the troubled times of their construction as well as the individual features of their investors, is characterised by some elements of architectural shaping which cannot be ascribed exclusively to the modesty and openness of popular devoutness. The Komrčar church on the island of Rab, once belonging to the Third Order, has long been recognised as innovative based on the parts of its applied architectural and decorative solutions, but it is less known that similar elements are also present in the monastery church in Glavotok. Once adopted, echoes of the applied conceptions are also to be found in Porat and Martinščica. St. Mary's church in Bijar on the island of Osor is an example where the previous architectural layer, from the period before the arrival of the Third order, has been preserved the best, whereas the monastery of St. Nicholas in Porozine represents splendidly the function of controlling communications, a role Tertiary monasteries once played in the Kvarner Gulf. Models for the creation of a peculiar Quarnaro Tertiary style can be found in the wider Adriatic area from Venice to as far as Osor and Šibenik, but we were also able to establish some similarities in the applied building solutions in the architecture of the Pauline Order in Istria and the coastal region in the same period. The paper also addresses the characteristic locations of Tertiary monasteries in the Kvarner islands, with the presence of fortification elements and other features of their architecture, the decoration of the fronts and the interior, especially the sanctuary, the original appearance of some details in architectural structures that have been altered in later periods, the sculptors and stone masons that decorated the Tertiary temples, in short - with the individual moment in history that produced these valuable monuments of the Quarnaro cultural landscape. In conclusion, an analysis of the monastery of St. Francis in the town of Krk is given, although originally it did not belong to the Kvarner Tertiary body of buildings. The analysis stresses the exceptional multi-layered complexity of the monastery, above all significant remnants of the architecture and sculpture of the Romanesque layer of the Benedictine St. John's church, followed by the important role of the original Franciscan church in the dissemination of Gothic elements in the Kvarner area, the episode with the extension of the church at the beginning of Venetian rule on the island of Krk, specimens of Renaissance stone masonry as well as the shaping of the cloister etc.

Keywords: Franciscans of the Third Order, architectural heritage, Kvarner islands. Ključne riječi: Franjevci trećoreci, arhitektonska baština, Kvarnerski otoci.

Marijan Bradanović

Filozofski fakultet Sveučilišta u Rijeci HR-51000 Rijeka Sveučilišna avenija 4, mbradanovic@ffri.hr 


\section{FILOZOFSKI FAKULTET SVEUČILIŠTA U ZAGREBU \\ ZAVOD ZA HRVATSKU POVIJEST \\ INSTITUTE OF CROATIAN HISTORY \\ INSTITUT FÜR KROATISCHE GESCHICHTE}

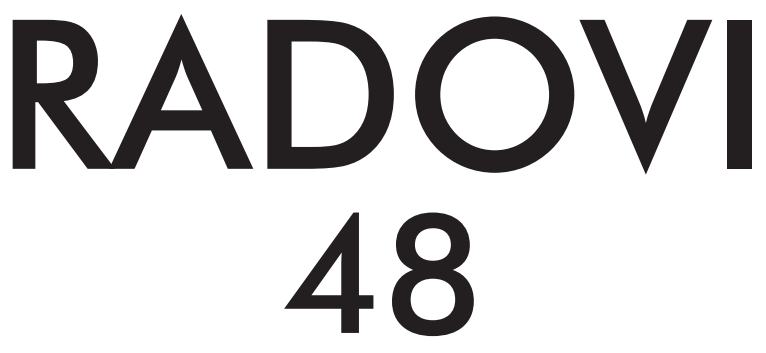

ZAVOD ZA HRVATSKU POVIJEST

FILOZOFSKOGA FAKULTETA SVEUČILIŠTA U ZAGREBU

\section{FF press}

ZAGREB 2016. 


\title{
RADOVI ZAVODA ZA HRVATSKU POVIJEST FILOZOFSKOGA FAKULTETA SVEUČILIŠTA U ZAGREBU \\ Knjiga 48
}

\author{
Izdavač / Publisher \\ Zavod za hrvatsku povijest \\ Filozofskoga fakulteta Sveučilišta u Zagrebu \\ FF-press \\ Za izdavača / For Publisher \\ Željko Holjevac \\ Glavni urednik / Editor-in-Chief \\ Hrvoje Gračanin \\ Izvršna urednica / Executive Editor \\ Inga Vilogorac Brčić \\ Uredništvo / Editorial Board
}

Bruna Kuntić-Makvić (stara povijest/ancient history), Zrinka Nikolić Jakus (srednji vijek/ medieval history), Hrvoje Petrić (rani novi vijek/early modern history), Željko Holjevac (moderna povijest/modern history), Tvrtko Jakovina (suvremena povijest/contemporary history),

Silvija Pisk (mikrohistorija i zavičajna povijest/microhistory and local history),

Zrinka Blažević (teorija i metodologija povijesti/theory and methodology of history)

Međunarodno uredničko vijeće / International Editorial Council

Denis Alimov (Sankt Peterburg), Živko Andrijašević (Nikšić), Csaba Békés (Budapest), Rajko Bratož (Ljubljana), Snježana Buzov (Columbus, Ohio), Svetlozar Eldarov (Sofija), Toni Filiposki (Skopje), Aleksandar Fotić (Beograd), Vladan Gavrilović (Novi Sad), Alojz Ivanišević (Wien),

Egidio Ivetić (Padova), Husnija Kamberović (Sarajevo), Karl Kaser (Graz),

Irina Ognyanova (Sofija), Géza Pálffy (Budapest), Ioan-Aurel Pop (Cluj),

Nade Proeva (Skopje), Alexios Savvides (Kalamata), Vlada Stanković (Beograd), Ludwig Steindorff (Kiel), Peter Štih (Ljubljana)

\section{Izvršna urednica za tuzemnu i inozemnu razmjenu / Executive Editor for Publications Exchange \\ Kristina Milković}

Tajnik uredništva / Editorial Board Assistant
Dejan Zadro

Adresa uredništva/Editorial Board address

Zavod za hrvatsku povijest, Filozofski fakultet Zagreb, Ivana Lučića 3, HR-10 000, Zagreb

Tel. ++385 (0)1 6120 150, 6120 158, faks ++385 (0)1 6156879

Časopis izlazi jedanput godišnje / The Journal is published once a year

Časopis je u digitalnom obliku dostupan na / The Journal in digital form is accessible at Portal znanstvenih časopisa Republike Hrvatske „Hrčak“ http://hrcak.srce.hr/radovi-zhp

Financijska potpora za tisak časopisa / The Journal is published with the support by

Ministarstvo znanosti, obrazovanja i športa Republike Hrvatske

Časopis je indeksiran u sljedećim bazama / The Journal is indexed in the following databases:

Directory of Open Access Journals, EBSCO, SCOPUS, ERIH PLUS, Emerging Sources Citation Index - Web of Science 


\section{Naslovna stranica}

Iva Mandić

Grafičko oblikovanje i računalni slog

Marko Maraković

\section{Lektura}

Samanta Paronić (hrvatski / Croatian)

Dražen Nemet (engleski / English)

Tisak

Tiskara Zelina d.d., Sveti Ivan Zelina

Naklada

250 primjeraka

Časopis je u digitalnom obliku dostupan na Portalu znanstvenih časopisa Republike Hrvatske ,Hrčak" http://hrcak.srce.hr/radovi-zhp

The Journal is accessible in digital form at the Hrcak - Portal of scientific journals of Croatia http://hrcak.srce.hr/radovi-zhp 


\section{RADOVI 48}

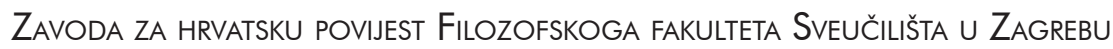

